\title{
Anti-AIDS strategy targets immune system
}

San Francisco. The National Institute of Allergy and Infectious Diseases (NIAID), frustrated with traditional, small-molecule, drug-based approaches to AIDS, has launched a programme to bring research institutions together for work on novel, immune-based strategies.

NIAID said it would dedicate \$25 million over the next four years to the Strategic Program for Innovative Research on AIDS Treatment (SPIRAT) for approaches such as restoration of the immune system, gene therapy and DNA-based therapeutic vaccines.

"This effort is crucial because currently available anti-HIV drugs only partially and temporarily suppress replication of the virus," says Anthony Fauci, director of NIAID.

AIDS treatment activists said SPIRAT, although a small part of NIAID's $\$ 558$ million AIDS budget, represented a major shift in focus that has been long overdue for the US agency. Even conservative AIDS researchers are beginning to shift their focus to immunological strategies as it becomes clear that antivirals alone will not be effective, said Mark Harrington of the Treatment Action Group in New York.

Activists lamented, however, that the funding appears to come at the expense of another programme, the National Cooperative Drug Discovery Groups for the Treatment of HIV (NCDDG). That effort, which fostered industry collaborations with academia, is being scaled down.

David Ho, director of the Aaron Diamond Research Center in New York and a member of the National Task Force on AIDS Drug Development, said any shutdown of NCDDG would leave a void. Pharmaceutical companies with the tools to continue the pursuit of small-molecule drugs need incentives to remain in AIDS research, he said.
Nava Sarver, an acting branch chief in the division of AIDS at NIAID, said that setaside funds for NCDDG had been discontinued. But researchers can still apply for investigator-initiated, unsolicited support under the NCDDG framework. "We are very, very eager to continue the programme," Sarver said.

NIAID is encouraging industry participation in the new grants, and four of the six university-based researchers with initial SPIRAT grants have corporate collaborators. The teams are to receive about $\$ 1$ million a year for four years, with early studies in humans to start by the third year.

Harrington and other activists said the new programme's inter-institutional approach would help bridge a gap in AIDS research between the laboratory and the clinic by encouraging greater interaction between clinicians and those working at an

early stage in the research.

"There's been a brick wall between the two," said Martin Delaney, an activist with Project Inform in San Francisco and a member of the AIDS Research Advisory Committee of NIAID. All too often treatment approaches die because of poor communication between basic scientists and clinicians, he said.

The projects include several techniques to bolster the immune system response by manipulating $\mathrm{T}$ cells, adding cytokines or infusing cells from non-infected sibling donors. Gene therapy strategies would concentrate on a defective gene from HIV for use in children, and an antiviral gene to produce ribozymes that would inactivate part of HIV. A vaccine-based approach would inject non-infectious HIV genes into the muscle tissue of HIV-infected people.

Sally Lehrmann

\section{US blocks return of reactor fuel}

Munich. South Carolina has placed an injunction on the US Department of Energy to stop it bringing highly enriched uranium (HEU) waste from research reactors in Europe for storage at the Savannah River Site in South Carolina.

Waste from four research reactors - in Holland, Sweden, Norway and Austria was dispatched by ship last week. But a day later, South Carolina's governor, Carroll Campbell, filed a suit against the Department of Energy, claiming that the European countries should store the waste on their own territory, and that a proper evaluation of the impact of the waste on the state's environment had not been carried out.

The move comes as a major blow to the

\section{CNRS puts lab equipment orders in suspense}

Paris. Sun-tanned and relaxed after the traditional long French summer break, laboratory heads returning to the Centre National de la Recherche Scientifique (CNRS) institutes throughout France may have turned pale on seeing the message feeding through their fax machines from the newly appointed director-general, Guy Aubert: "suspend all orders paid out of CNRS funds".

Aubert, barely in the job two months, has moved swiftly to avert an impending financial crisis at CNRS. In a bid to obtain an accurate picture of CNRS finances, he has also asked laboratory heads to supply him with a list of all orders already passed, and estimates for spending until the end of the year. Only then will he let staff know how much they can spend.
Researchers seem to have accepted the action as inevitable - and even overdue. The financial problem has arisen because CNRS laboratories spend money according to promises made by the government in the annual budget, whereas actual cash payments often lag behind.

Indeed, while Aubert's action is an emergency measure, he is keen to end what he describes as obsolete financial management at CNRS. He plans to create a new system, for example reducing the number of staff authorized to make equipment purchases and increasing the accountability of laboratory heads. Last year, many suppliers went unpaid until laboratories received their 1994 budget; Aubert believes such a situation is bad for CNRS's image.

Declan Butler
US anti-nuclear proliferation agency, the Nuclear Control Institute (NCI), which has been actively engaged in persuading the four research reactors to convert to the use of low enriched uranium (LEU) (see Nature 369, 89; 1994).

Part of the agreement was that the United States would handle all radioactive waste from the reactors immediately, as each was close to the limits of their licences for storing waste at their own sites. The Department of Energy's approval of immediate dispatch of the waste was received in June.

Marcel de Bruin, director of one of the research reactors at Delft in the Netherlands, says that if the department is unable to mount a successful challenge to the injunction, he will have to consider sending his waste to the United Kingdom for reprocessing - a move which would contravene current policy in both the United States and Holland.

De Bruin said he would also have to reconsider the agreed expensive conversion to LEU. "If these research reactors start to take such steps", says a spokesman for the Nuclear Control Institute, "the whole policy on controlling nuclear proliferation could collapse".

The National Resources Defense Council, an environmental group based in Washington, has joined the Nuclear Control Institute and the research reactors in challenging the injunction. All three have criticized the timing of Campbell's injunction, pointing out that it was issued after the two ships bearing the highly radioactive cargo had set sail, and left the cargo potentially vulnerable to accident or terrorist attacks.

Alison Abbott 